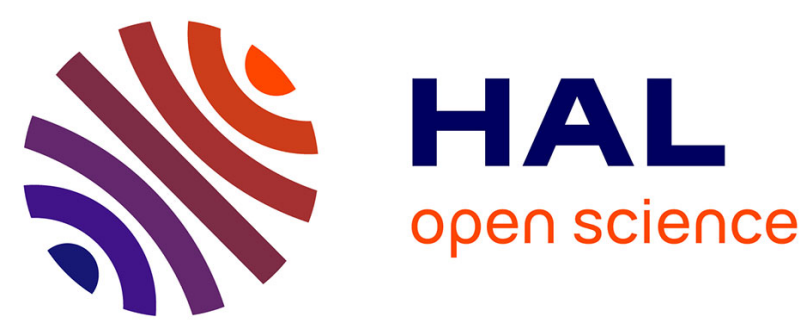

\title{
Contextual Design of Intelligent Food Carrier in Refrigerator: An Indian Perspective
}

\author{
Pritam Kale, Ganesh Bhutkar, Virendra Pawar, Nikhil Jathar
}

\section{To cite this version:}

Pritam Kale, Ganesh Bhutkar, Virendra Pawar, Nikhil Jathar. Contextual Design of Intelligent Food Carrier in Refrigerator: An Indian Perspective. 4th IFIP 13.6 Working Conference on Human Work Interaction Design (HWID), Jun 2015, London, United Kingdom. pp.212-225, 10.1007/978-3-31927048-7_15 . hal-01371801

\section{HAL Id: hal-01371801 https://hal.inria.fr/hal-01371801}

Submitted on 9 Nov 2016

HAL is a multi-disciplinary open access archive for the deposit and dissemination of scientific research documents, whether they are published or not. The documents may come from teaching and research institutions in France or abroad, or from public or private research centers.
L'archive ouverte pluridisciplinaire HAL, est destinée au dépôt et à la diffusion de documents scientifiques de niveau recherche, publiés ou non, émanant des établissements d'enseignement et de recherche français ou étrangers, des laboratoires publics ou privés. 


\title{
Contextual Design of Intelligent Food Carrier in Refrigerator: An Indian Perspective
}

\author{
Pritam Kale ${ }^{1}$, Ganesh Bhutkar ${ }^{2}$, Virendra Pawar ${ }^{2}$, Nikhil Jathar ${ }^{3}$ \\ ${ }^{1}$ PG Research Scholar, Vishwakarma Institute of Technology (VIT), Pune, India \\ Kalepritam91@gmail.com \\ ${ }^{2}$ Assistant Professor, Vishwakarma Institute of Technology (VIT), Pune, India. \\ ${ }^{3}$ Director, Avansaber Technologies Pvt. Ltd., Pune, India.
}

\begin{abstract}
Refrigerators are used to store food items mainly in food carriers such as plastic boxes, trays or bags. This research paper is focused on Contextual Inquiry (CI) of refrigerators and related contextual design of egg tray. To understand user perspectives about refrigerators, food items, food carriers and related problems, a CI is conducted with 19 home users from 12 households. The CI has provided vital insights into several major aspects of refrigerators, their usage and user interaction. For example, the maximum weight of a food item stored in refrigerator is about $2 \mathrm{Kg}$. The selected food carrier for implementation is an egg tray. Such intelligent tray is a specially designed food carrier using a load cell for sensing a weight of eggs stored on it. Thus, a contextual design of egg tray helps in providing information about number of eggs stored on a egg tray. In future, this research work will be extended to other food carriers and related mobile App.
\end{abstract}

Keywords: Contextual design, Contextual inquiry, Refrigerator, Intelligent food carrier, Egg tray.

\section{Introduction}

A refrigerator is common household appliance that consists of thermally insulated compartment and a heat pump that transfers heat from inside to external environment so that the inside environment remains cool [6]. It is used to store food items as it reduces a rate of food spoilage. The refrigerators are used for domestic, commercial, industrial or biomedical purposes. The domestic refrigerators can be categorized according to their storage capacity in Liters (L) from $165 \mathrm{~L}$ to $310 \mathrm{~L}$ or more [18]. This research work is focused on domestic refrigerators, which are mainly utilized by home users such as home makers, children or other family members. Domestic refrigerators are used to store cooked food items, vegetables, beverages, and other. The food storage in such refrigerator is depicted in Fig. 1. These users face major problems such as unavailability of required food items, identification of expired food items, undesired temperature control, more power usage, insufficient storage space and continuously irritating noise [6]. Therefore, home users need solutions, which cater to deal with such problems. In this paper, Contextual Inquiry (CI) is conducted for better understanding of existing system of food storage and management in refrigerators. Then, the work models are developed and incorporated in proposed contextual design of intelligent food carrier - an egg tray. 


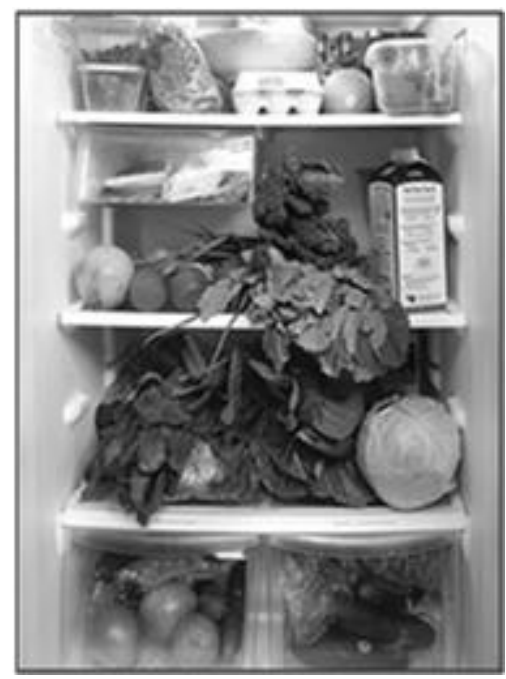

Fig. 1. Food storage in domestic refrigerator

\subsection{Related Work}

Initially, the research papers related with intelligent refrigerators and food carriers are studied. The first study has presented an intelligent refrigerator with monitoring capability through the Internet. It has an Infrared (IR) sensor, which detects a presence of food item in the refrigerator [21] and it does not inform about item quantity as well as reorder level. Another study has discussed about automatic Chinese food identification and quantity estimation. It identifies food item quantity through a color and texture by using two cameras for size and depth [4]. When refrigerator door is closed, it fails to detect the food items in dark, which is its major limitation. A next study has presented a child-centric food advisory enabled smart system for refrigerators. It is designed especially for children and has face recognition using a camera. It provides an access to child compartment only; hiding other compartments to promote healthy food habits [20]. These studies have helped in understanding different perspectives of smart refrigerators. All studies have used image processing for detection of food items. The use of multiple and specialized cameras increases the cost of designs and also requires presence of light for item detection. To deal with these aspects, we have proposed more economical and generic solution in the form of intelligent food carriers using much cheaper sensors such as load cells for home users to detect food item quantity and to set reorder levels.

There is an Android-based App - 'Food Buddha', which helps users efficiently in managing their food items [7]. This application tracks food item expiration and quantity in percentage. The inputs are provided through manual data entry and Quick Response (QR) code. A sample QR code for food item is depicted in Fig.2. Many food items do not have QR codes and it is not easy to generate these codes; if 
required. Therefore, this application can be used only with food items with QR codes. Also, manual data entry is not preferred by many users.

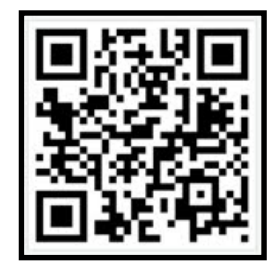

Fig. 2. Quick Response (QR) code

Next study has discussed about smart egg tray named egg minder which informs only quantity of eggs i.e. in number and oldest egg put into egg tray by user which doesn't inform actual freshness of eggs. A major problem in this system, there are use of verity of food items in domestic refrigerator. These food items are measured into number, kilogram and liter but such system suitable for those food items which quantity can measure into number. User needs to alert whenever quantity of food item goes to below certain level i.e. reorder level and there should be facility to set reorder level according to user's requirement [8].

Following are the major research papers studied to understand the process of $\mathrm{CI}$ as well as related design. A CI of car drivers has been conducted for design of application - 'Infotainment' [10]. This CI study consists of 6 real-life travel trips with a total of 8 drivers. It suggests that even though, driving itself has remained relatively unchanged; there are now a wide variety of new in-car tasks, which drivers perform such as road tracking, weather forecasting, listening music or exploring news along with social media. The drivers have preferred gesture interaction and notification of changes in the driving context. Another study is aimed at building an understanding of Automatic Teller Machine (ATM) adoption in Mumbai, India through CI, in which 20 ATM users are involved [1]. The collected data has been analyzed to identify specific cultural traits related with power distance, collective orientation and communication boundaries. The results demonstrate the unique role of the cultural context in affecting user expectations and behavioral possibilities.

\section{Methodology}

The methodology of research work for the design of intelligent food carrier has three major steps, which include CI, development of work models and related effective design of intelligent food carrier [12].

- Contextual inquiry: It is a technique of studying users in their own natural environment to get insight, understand their requirements and identify related usability problems. It involves data collection from several households to explore domestic refrigerators, their home users, related food carriers and food items. 
- Development of work models: The work models include categorization of users, their roles, beliefs, values, work tasks, details of work space and artifacts. Six work models are developed and they include flow, sequence, cultural, physical, artifact and sensory models $[11,13]$.

- Design of intelligent food carrier: The food carrier design is represented in terms of an architecture design, which specifies development constraints as well as software and hardware requirements. An intelligent food carrier is a specially designed carrier using a load cell, which is used to detect food item quantity in number or kilogram.

\section{Contextual Inquiry}

During CI, several households have been visited to study domestic refrigerators and their home users. These users have been observed interacting with refrigerators. Their behavior and responses have been investigated through interviews and discussions. CI has helped in understanding user categories, artifacts, customs, systems, problems and requirements. The data analysis in CI, has led to development of related work models $[13,14]$.

Table 1. Food item details

\begin{tabular}{|c|c|c|c|c|}
\hline $\begin{array}{l}\text { Food } \\
\text { Item }\end{array}$ & $\begin{array}{l}\text { Item } \\
\text { Type }\end{array}$ & $\begin{array}{l}\text { Average } \\
\text { Quantity }\end{array}$ & $\begin{array}{c}\text { Food Carriers } \\
\text { used in } \\
\text { Storage }\end{array}$ & $\begin{array}{l}\text { Number of } \\
\text { Households }\end{array}$ \\
\hline Tomato & $\begin{array}{c}\text { Fruit } \\
\text { vegetable }\end{array}$ & $\begin{array}{c}2 \\
\mathrm{Kg}\end{array}$ & Plastic box & 10 \\
\hline Beans & $\begin{array}{c}\text { Fruit } \\
\text { vegetable }\end{array}$ & $\begin{array}{c}1 \\
\mathrm{Kg}\end{array}$ & Plastic bag & 09 \\
\hline Cabbage & $\begin{array}{c}\text { Leafy } \\
\text { vegetable }\end{array}$ & $\begin{array}{c}1 \\
\text { Kg }\end{array}$ & $\begin{array}{c}\text { Plastic bag / } \\
\text { On rack }\end{array}$ & $\begin{array}{l}05 \\
04\end{array}$ \\
\hline Lemon & $\begin{array}{c}\text { Fruit } \\
\text { vegetable }\end{array}$ & 8 & Tray & 08 \\
\hline Egg & $\begin{array}{l}\text { Poultry } \\
\text { product }\end{array}$ & 8 & Tray & 06 \\
\hline Milk & $\begin{array}{c}\text { Dairy } \\
\text { product }\end{array}$ & $\begin{array}{l}2 \\
\mathbf{L}\end{array}$ & $\begin{array}{c}\text { Plastic bag / } \\
\text { Steel vessel }\end{array}$ & $\begin{array}{l}06 \\
04\end{array}$ \\
\hline Curd & $\begin{array}{c}\text { Dairy } \\
\text { product }\end{array}$ & $\begin{array}{l}0.5 \\
\mathrm{Kg}\end{array}$ & Steel bowl & 06 \\
\hline Buttermilk & $\begin{array}{c}\text { Dairy } \\
\text { product }\end{array}$ & $\mathbf{L}$ & Steel vessel & 06 \\
\hline $\begin{array}{c}\text { Ghee } \\
\text { (Clarified } \\
\text { butter) }\end{array}$ & $\begin{array}{c}\text { Dairy } \\
\text { product }\end{array}$ & $\begin{array}{l}0.5 \\
\mathrm{Kg}\end{array}$ & $\begin{array}{c}\text { Glass / } \\
\text { Plastic jar }\end{array}$ & 06 \\
\hline
\end{tabular}

A field work is essential for observing user interaction and understanding real requirements of home users dealing with refrigerators. Twelve households have been visited in and around city of Pune, India including both - rural and urban areas. It includes interaction with 19 participant users. These users include 9 Homemakers, 4 
children and 6 other family members. This is a convenient sampling of home users, who have been targeted during CI just like other CI studies [1, 12]. Each household has been visited about 3 times and about 10 questions related with household details, experiences with refrigerator and food storage pattern are asked to users. The details of food items stored in refrigerators used in visited households are provided in Table 1. A few interesting trends about food items are observed during field work as seen in this Table. The most important food items stored in domestic refrigerators are Tomatoes, Beans, Cabbage, Lemons, Milk and Eggs. Most of the stored food items are measured in Kilogram $(\mathrm{Kg})$ and maximum weight for food item stored is $2 \mathrm{Kg}$. The food items are stored mainly in plastic boxes, trays or plastic bags. Most of the users face a problem of insufficient storage capacity of refrigerators. Many food items are hidden deeper in the storage and it is difficult to find out expired food items.

\section{Work Model}

There are six work models, which are developed during CI [13, 14]. Developing such models is a time consuming process as it involves intensive field work, observing user interactions, interviewing users and data analysis. These six models are discussed in this section.

\subsection{Flow Model}

It is focused on identifying roles and responsibilities of different types of users [5, 6]. There are three types of home users viz. homemakers, children and family members. A homemaker is a primary user, who is relatively more active and acts as a decision-maker whereas; children and other family members are secondary users [2].

- Homemaker: A homemaker is a person whose main job is to take care of his or her own family home and children. Traditionally, the job of homemaker is done by women. She is involved in many activities such as food storage, quantity detection, message communication and monitoring the refrigerator condition. She pays special attention to milk products and also keeps a watch on the expired food items and temperature condition.

- Children: They are secondary users of domestic refrigerators. They are mainly interested in food items such as chocolates, ice-creams and cakes.

- Family members: They are also secondary users of domestic refrigerators. They are involved in food storage, quantity detection, message communication and repairing refrigerator. The repairing activity may involve getting rid of problems related with refrigerator components such as compressor, defrosting heater or condenser coil. 


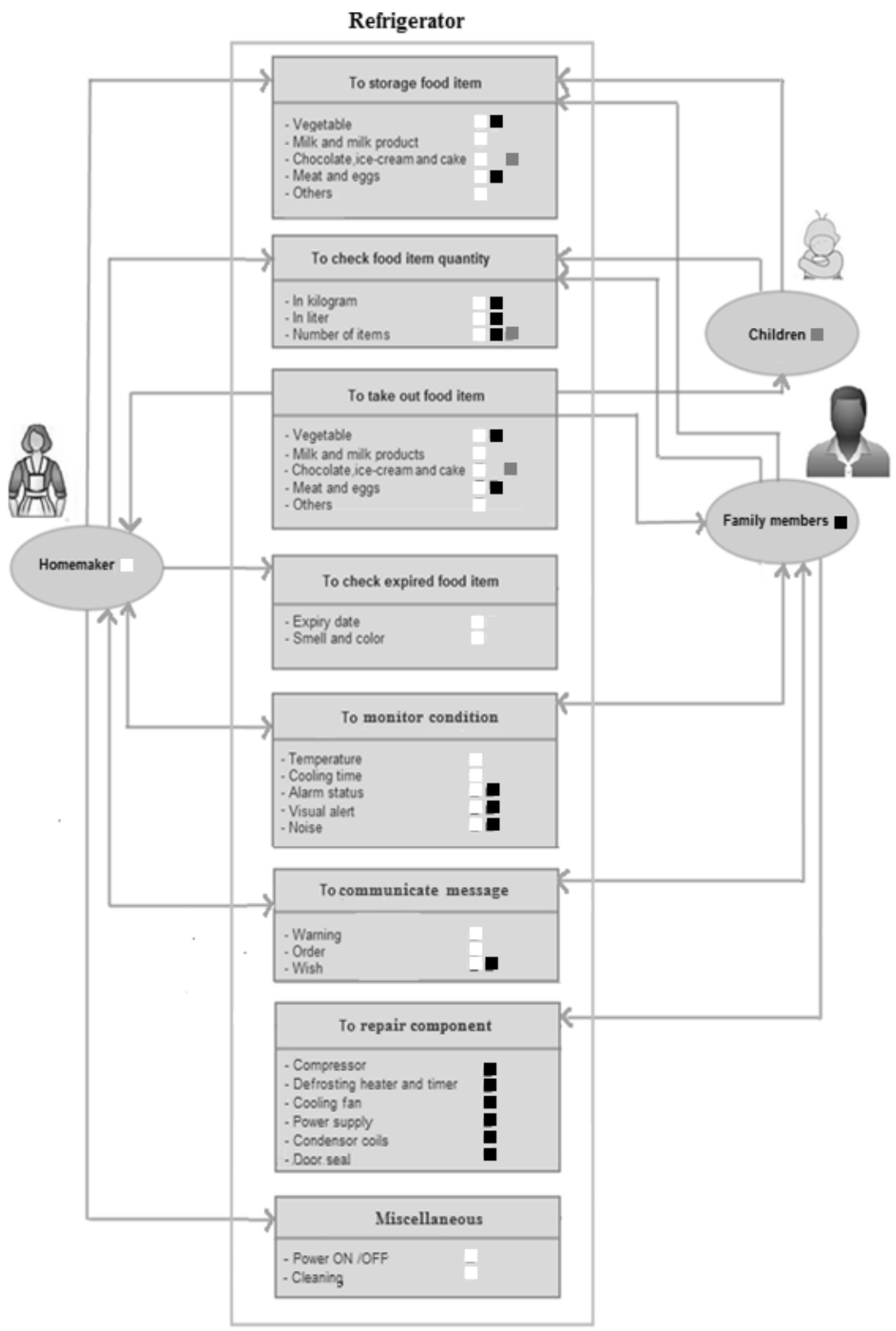

Fig. 3. Flow model for domestic refrigerator

In Fig. 3, three main user types - homemaker, children and family members are shown enclosed in ellipses. The activities associated with user roles and 
responsibilities related with refrigerator, are represented using rectangles. If user is involved in an activity, a link has been created between that activity and a related user. Each activity has many items or parameters and related users are represented with smaller squares in white, black and gray respectively. For example, both - home maker and other family members communicate a message using refrigerator wall. A home maker communicates a message related with order, warning or wish; whereas other family members mostly pass on wish messages.

\subsection{Sequence Model}

It represents tasks and related action sequences involved in task completion, and highlights possible problems [5]. So, it brings out related problems which are faced by users while executing specific action sequence during user interaction with the system [15]. There are several important tasks such as storage of food item, checking out its quantity and expiry, monitoring condition, cleaning of food carriers and so on. One such important sample task is 'To check food item quantity'. It has several steps as depicted in Fig. 4. There are four problems identified during execution of related action sequence. These numbered problems are shown between successive steps and they include food item unavailable, may notice expired food item, may forget to purchase required food item, door opened or not closed properly.

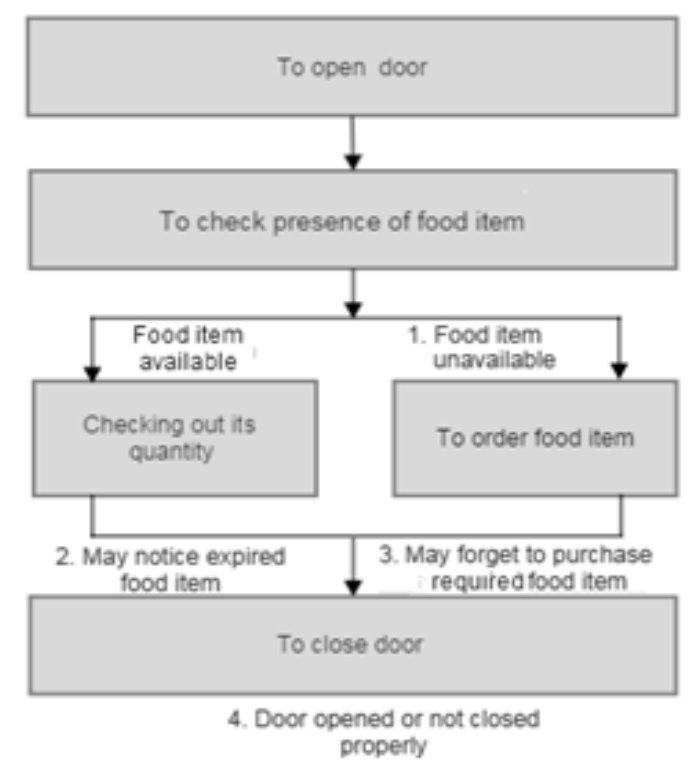

Fig. 4. Sequence diagram for a task - 'To check a quantity of food item' 


\subsection{Cultural Model}

This model is used to understand the beliefs, values, customs, pressures and frustrations of the users in a specific domain [5, 14]. During CI of home users using refrigerators, following cultural observations are made:

- Homemaker: A homemaker takes care that food items are utilized effectively and are not wasted. A value for money is a vital consideration for reordering of food items. She has to remember festivals, fasts, events and special occasions such as birthdays and anniversaries as she has to plan recipes accordingly. She has to see that recipes are not repeated frequently and are served as per the preferences and requirements of children and other family members. For example, older family members may be diabetic and may require sugar control in daily diet. It is observed that about $56 \%$ (5 out of 9) of these women have smart phones with Internet connectivity. About 44\% (4 out of 9) of them have Android-based phones and they use selected Android Apps frequently.

- Children: They are naughty and like to explore and get access food items. They play with refrigerator door or even, temperature control regulator. To avoid these problems, refrigerator in one of the households is found locked.

- Family members: They may be involved in purchasing of food items from the market. For a family member, visiting market after returning home from work, is extremely irritating experience. Young family members actively participate in exchange of messages and wishes on refrigerator door. If family member is senior citizen, he / she may forget to purchase food items on time or may miss out the refrigerator alarm. It is observed that about 67\% (4 out of 6) of these other family members have smart phones with Internet connectivity. About 50\% (3 out of 6) of them have Android-based phones and they use selected Android Apps frequently.

It is also found that home users prefer more economical refrigerators and food carriers in terms of both - the price and energy consumption. Most of the households prefer fresh vegetables and many branded food items. About 33\% (4 out of 12) of households visited are Indian vegetarians, who do not eat eggs, fish and meat. The food items stored in refrigerators of such vegetarian households contain larger quantity of pickles, sauces, chutneys, juices and lemons. About 83\% (10 out of 12) of households visited have five-star rated refrigerators, which have low energy consumption [20].

\subsection{Physical Model}

It involves the analysis of workspace dynamics. It is represented by a floor plan and arrangement [3] of related entities [5]. In CI, it is observed that the refrigerator is placed mostly in a kitchen as depicted in Fig. 5(a). If kitchen is smaller, then the refrigerator may be placed in other room (bedroom or hall) adjacent to the kitchen as seen in Fig. 5(b). If the position of refrigerator is far from the kitchen, then, users do not approach the refrigerator frequently and may store food item after a considerable 
delay. Many users may even forget to store the food items. This may lead to wastage or quality degradation of food items.

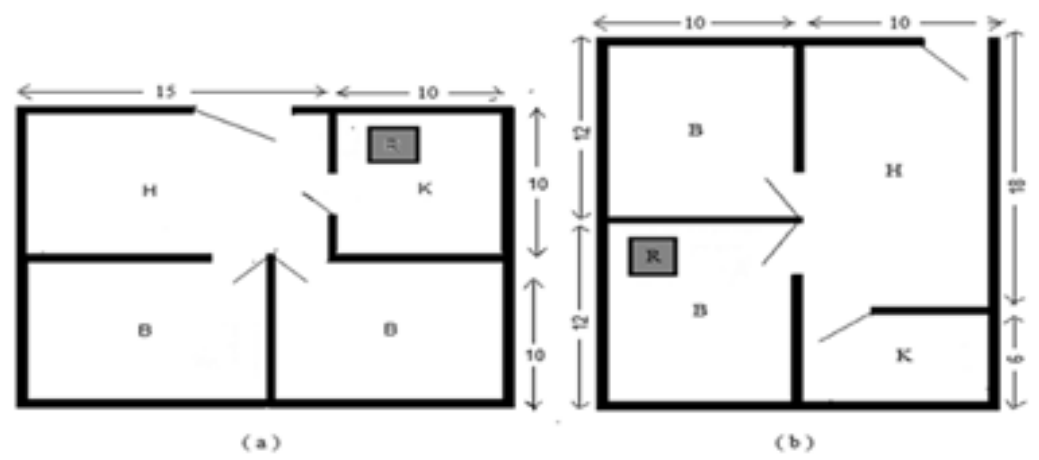

Fig. 5. Physical model depicting place of refrigerators in households

\subsection{Artifact Model}

It is used to understand the availability and use of artifacts. It also helps to list artifacts highlighting anything that has a potential to make a difference towards an efficient and effective working environment [5, 14]. The important artifacts observed during home user interaction with refrigerators include power stabilizers, inverters, food carriers, pasted messages or door locks along with a verity of food items. Food carriers are shown in Fig. 6.

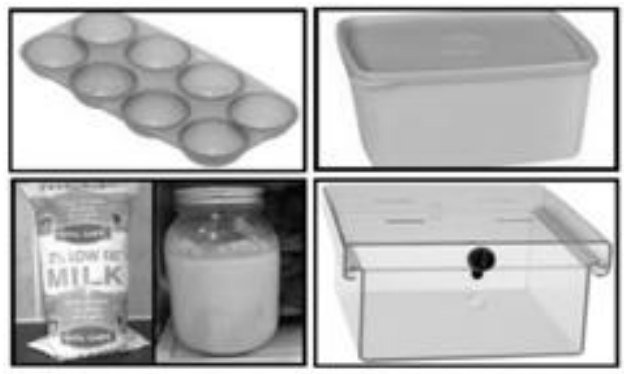

Fig. 6. Food carrier in refrigerator

\subsection{Sensory Model}

It includes listing all the materialistic and non-materialistic aspects that contribute to the experience of using the system [14]. An audio alarm can be heard when refrigerator door remains opened for a long time. Sometimes, an irritating noise can be heard from a refrigerator. Also, many refrigerators generate visual indicators for power ON / OFF status and variations in cooling levels. One such indicator in the form of LED is depicted in Fig. 7. 


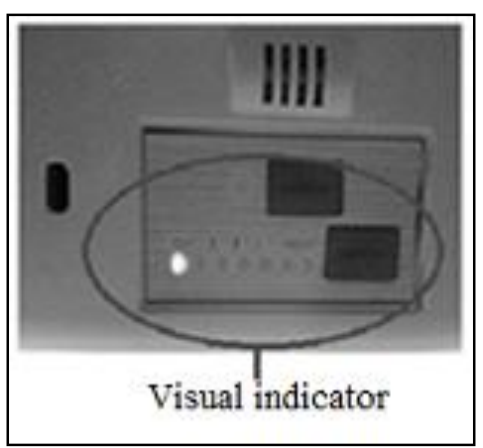

Fig. 7. Visual indicator

\section{Aspects derived from CI and Related Models for Design of Intelligent Food Carrier}

Following are important aspects derived from CI and related models for preliminary design of intelligent food carrier:

- Important food items stored in refrigerators are vegetables, milk, lemons and eggs. Surprisingly, fruits are not stored in refrigerators in majority of the households. These items are stored mainly in food carriers such as plastic boxes, trays or plastic bags. In vegetarian households, lemons are stored on egg trays.

- The maximum weight of food items stored in refrigerator is about 2 kilograms; which may increase up to $3 \mathrm{Kg}$ on special occasions. Therefore, load cell [9] for sensing system should be selected accordingly.

- Food items have different reorder levels and home users may not remember them. If stored food item quantity goes below reorder level, the home user requires information about it through mobile alert for reordering the food item.

- Food items stored in refrigerator vary as per the seasons and festivals celebrated.

\section{Design of Intelligent Food Carrier}

The food carriers in refrigerators include plastic trays, bags, jars, boxes, bowls or steel vessels. The design of these food carriers can be extended to that of intelligent food carriers. During the present research work, an egg tray is selected and its contextual design is proposed. A major user requirement as per the flow model depicted in Fig. 3 is to check out egg quantity stored on the egg tray. Other problems observed in the sequence model shown in Fig. 4 include unavailability of food item and user behavior of forgetting the purchase of required food item(s). The aspect of reorder level setting for eggs and generating related alert message is vital for home 
users. Such requirements and problems are addressed in contextual design of egg tray. Thus, an intelligent egg tray design is provided to the home users supporting remote access and effective communication for today's busy life style

\subsection{An Architecture Design of Intelligent Food Carrier}

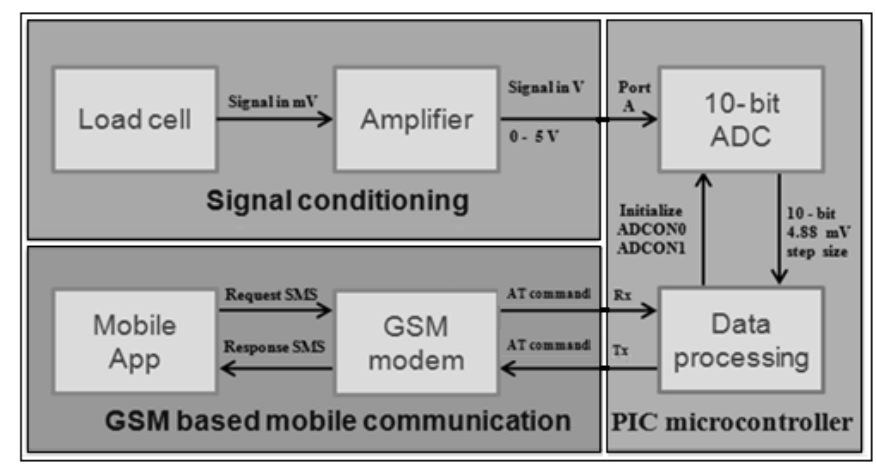

Fig. 8. Architectural diagram of intelligent food carrier for quantity detection

An architectural design of sample intelligent food carrier for quantity detection is depicted in Fig. 8. It has three major compartments viz. Signal conditioning, Microcontroller and Global System for Mobile Communications (GSM) based mobile communication. These compartments are discussed below:

- Signal conditioning: It has two separate blocks representing a load cell and an amplifier respectively. A load cell generates an electrical signal in $\mathrm{mV}$ as per the load [9, 19] i. e. a weight of food item. An amplifier is used to convert an electrical signal from $\mathrm{mV}$ to $\mathrm{V}$ since $1 \mathrm{mV}$ equal to one thousandth $\left(10^{-3}\right)$ of a volt and Analog to Digital Converter (ADC) have one step size near about $5 \mathrm{mV}$ [19]. Thus, this Signal conditioning compartment provides an amplified signal (in V) of the load cell.

- Microcontroller: It receives an amplified signal from Signal conditioning compartment. It has two major blocks viz. a 10-bit ADC and Data processing program respectively. It has 10-bit ADC which generates binary value with step size of $4.88 \mathrm{mV}[16,19]$. It also has Data processing program, which is complied in $\mathrm{C}$ and loaded on Read Only Memory (ROM) of microcontroller. This program processes binary input into decimal output representing item quantity. Such decimal output and AT commands are provided for further mobile communication. These AT commands control the modem and are defined by European Telecommunications Standards Institute (ETSI) in GSM 07.07, and GSM 07.05.

- GSM based mobile communication: It communicates message about food item quantity to the home users. It has two blocks such as GSM modem and Mobile App. The GSM modem communicates Short Message Service (SMS) message 
containing decimal output for item quantity to and from mobile phone. The mobile App displays the quantity of food item to the home user and facilitates in setting the reorder level of the food item.

\subsection{Load Cell and Its Parameters}

A load cell is a sensor that is used to create an electrical signal whose magnitude is directly proportional to the applied load being measured. A suitable load cell is selected for detection of food item quantity based on its weight. A load cell model CZL-601 is chosen based on its maximum load capacity of $3 \mathrm{Kg}$ and its temperature range of $-20^{\circ} \mathrm{C}$ to $+65^{\circ} \mathrm{C}$. The capacity of this load cell is selected as per the requirement for food storage, which is $2 \mathrm{~kg}$ (Section 5) as observed in contextual inquiry. It has a dimension of $30 \mathrm{~mm} \times 130 \mathrm{~mm}$ and an excitation voltage range of 5$12 \mathrm{~V}[17]$

\subsection{Implementation of Intelligent Egg Tray}

An egg tray is selected for implementation of intelligent food carrier as it stores 612 eggs only and the food item quantity often needs to be expressed in one or twodigit integer. This tray is also used for storage of lemons in vegetarian households. Therefore, the tray design may also be extended to lemon storage in future.
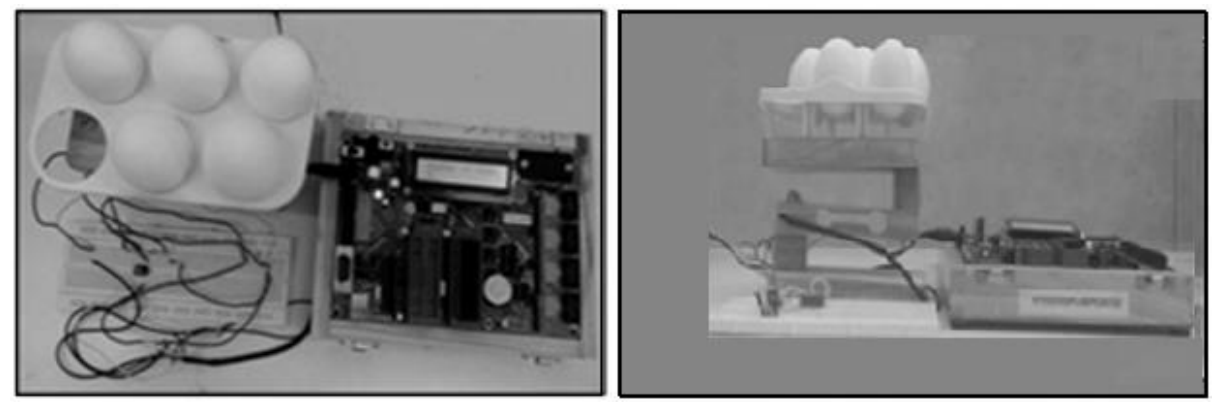

Fig. 9. Experimental setup of intelligent egg tray

An experimental setup of intelligent egg tray is depicted in Fig. 9. It consists of egg tray placed on the top of a load cell, which is connected to microcontroller kit through an amplifier circuit mounted on a breadboard as discussed in an architectural design in Fig. 8 [17]. The load cell (CZL-601) and microcontroller kit are provided with +5 $\mathrm{V}$ DC power supply. An Amplifier has $+5 \mathrm{~V}$ and - $5 \mathrm{~V}$ DC power supply with gain of 1000. An output pin of an amplifier is connected to port A (RA0) of a microcontroller - PIC18f4520. A 10-bit ADC in microcontroller kit is at fosc / 64 clock i.e $2 \mu \mathrm{s}$ (microseconds) with a $4.88 \mathrm{mV}$ step size. The part of GSM-based mobile communication have GSM modem which communicates the message about quantity of eggs and reorder level alert with mobile App through a SMS message. 


\subsection{Testing and Result}

Table 2. Observation table for egg tray

\begin{tabular}{|c|c|c|c|c|}
\hline $\begin{array}{l}\text { Eggs on Tray } \\
\text { in numbers }\end{array}$ & $\begin{array}{l}\text { Egg Weight } \\
\text { in gm }\end{array}$ & $\begin{array}{c}\text { ADC Step Sizes } \\
\text { in V }\end{array}$ & $\begin{array}{c}\text { Decimal } \\
\text { Value }\end{array}$ & $\begin{array}{l}\text { Egg Quantity } \\
\text { in numbers }\end{array}$ \\
\hline 01 & 48 & 0.024 & 6 & 01 \\
\hline 03 & 160 & 0.080 & 19 & 03 \\
\hline 07 & 368 & 0.168 & 40 & 07 \\
\hline 10 & 530 & 0.280 & 50 & 10 \\
\hline 12 & 650 & 0.320 & 58 & 12 \\
\hline
\end{tabular}

An intelligent egg tray is tested using its experimental setup as shown in Fig. 2 (b). The eggs are placed on egg tray and the result - egg quantity in numbers is observed on Liquid Crystal Display (LCD) display of microcontroller kit. It has been observed during experimentation that as average weight of eggs is $53 \mathrm{gm}$. It means a decimal value of 5-7 represents item quantity of $1 \mathrm{egg}$. Similarly, a value of 12-14 represents 2 eggs; a value of 19-21 represents 3 eggs and so on. The observation table for this testing is provided in Table 2, which shows that the design of intelligent egg tray is able count the number of eggs accurately.

\section{Conclusion and Future Work}

The CI and related six work models have highlighted many important aspects and requirements for refrigerator usage in Indian households. These aspects include selection of key food items, maximum quantity estimates, reorder levels and related home culture. The preliminary setup of an intelligent egg tray for refrigerators is designed and is able to detect the number eggs placed on an egg tray accurately.

In future, mobile communication will be implemented as per the architectural design of intelligent food carrier. The food carrier should differentiate between eggs and lemons. There is a plan of developing an Android-based App as a complete integrated solution for dealing with several user requirements identified in CI. Such contextual design can also be extended to the other food carriers used in refrigerators. It will help home users to reduce their frustrations with refrigerators and manage stored food items effectively. 


\section{Acknowledgements}

We would like to thank and appreciate help from Mr. Suresh Nagargoje, Mr. Rohit Kewalramani, Mr. Vinay Thamke and Mr. Pranay Nandanwar in assembling of electronic components and valuable suggestions. I also thank to Prof. Dhiraj Jadhav, Mr. Uday Sagale, Mr. Mahadev Karad, and Mr. Shrikant Savale in design of diagrams. I am very grateful to all the home users who participated in Contextual Inquiry.

\section{References}

1. Angeli A., Athavankar U., Joshi A., Coventry L., and Johnson G.: Introducing ATMs in India: A contextual inquiry. Interacting with Computers, 16(1), 29-44. (2004)

2. Bhutkar G., Katre D., Rajhans N., and Deshmukh S.: Scope of ergonomics and usability issues with intensive care unit (ICU): An Indian perspective. HFESA JournalErgonomics Australia, 22(1), 26-32. (2008)

3. Bhutkar G., Katre D., Ray G., and Deshmukh S.: Usability Model for Medical User Interface of Ventilator System in Intensive Care Unit. Human Work Interaction Design: Work Analysis and HCI. (2013)

4. Chen M., Yang H., Ho C, Wang S., Liu S., and other: Automatic Chinese food identification and quantity estimation. In SIGGRAPH Asia 2012, Singapore. (Nov. 2012)

5. Chinnapattan P.: A guide to conducting contextual inquiry user research. Accessed on 7th March, 2014 - http://www.webcredible.com/blog-reports/web-usability/contextualinquiry.shtml. (2013)

6. Devotta S., Sicars S., and others: Safeguarding the ozone layer and the global climate system. Special Report of the Intergovernmental Panel on Climate change. (Oct. 2005).

7. Food Budhha: Contextual inquiry. Accessed on 8th April 2014 https://sites.google.com/site/foodbuddhacorp/milesto nes/contextual-inquiry

8. Garun N.: Egg Minder smart tray lets you remotely check the freshness of your eggs.

Accessed on 8th Jul 2015 - http://www.digitaltrends.com/home/egg-minder-smarttray-lets-you-remotely-check-the-freshness-of-your-eggs/

9. Gross C. and Germanton D.: Load cell with bossed sensor plate for an electrical weighing scale. U.S. Patent 6,417,466, (July, 2002).

10. Heikkinen J., Mäkinen E., Lylykangas J., Pakkanen T., Väänänen-Vainio-Mattila K., and Raisamo R.: Mobile devices as infotainment user interfaces in the car: contextual study and design implications. In Proceeding of MobileHCI'13, Munich, Germany (Aug. 2013), 137-146. (2013)

11. Holtzblatt, K. "Contextual design." Human-Computer Interaction: Development Process (2009).

12. Holtzblatt K., and Hugh B.: Making customer-centered design work for teams. Communications of the ACM, 36(10), 92-103. (1993)

13. Hugh, B., and Holtzblatt, K.: Contextual design: Defining customer-centered systems. Morgan Caufmann Publications, San Francisco, USA. (1998)

14. Hung $Y$. and Winchester W.: Using contextual design techniques to identify work task problems in dynamic work environments - A field study of isolating safety challenges 
for small builders. In Proceeding of the Human Factors and Ergonomics Society $52^{\text {nd }}$ Annual Meeting, New York, USA (Sept. 2008), 1718-1722. (2008)

15. Jadhav D., Bhutkar G., and Mehta V.: Usability evaluation of messenger applications for Android phones using cognitive walkthrough. In Proceedings of the 11th Asia Pacific Conference on Computer Human Interaction, ACM. 9-18. (2013)

16. Jawarkar N., Vasif A., Siddharth A., and others: Micro-controller based remote monitoring using mobile through spoken commands. Journal of Networks, 3(2), 58-63. (2008)

17. Kale P., Pawar V., and Bhutkar G.: Design of intelligent food carrier for androidbased application - 'Refrigerometer', ICCIG3, IIM Ahmedabad. (2015)

18. McNeil M.: Progress towards managing residential electricity demand: Impacts of standards and labeling for refrigerators and air conditioners in India. Lawrence Berkeley National Laboratory - Accessed on $15^{\text {th }}$ June, 2014 https://escholarship.org/uc/item/6cd588t4.pdf. (2010)

19. Muhamma M., Mazidi J., McKinlay R., and Ingendorf P.: Pic microcontroller and embedded systems. Prentice-Hall, Inc. (2005)

20. Mulay P., Kumar, M., and Patil, S.: Child centric food advisory enabled smart system for refrigerators. IJCSMC, Vol. 3, Issue. 12, 507 - 513. (2014)

21. Nayak S., Gangadhar G., and Puttamadappa C.: Intelligent Refrigerator with monitoring capability through internet. 65-68. (2011) 